\title{
FAKTOR-FAKTOR RISIKO YANG BERHUBUNGAN DENGAN KEJADIAN PNEUMONIA PADA BALITA DI WILAYAH KERJA PUSKESMAS SARIWANGI KABUPATEN TASIKMALAYA TAHUN 2018
}

\author{
Wuri Ratna Hidayani ${ }^{1}$ \\ email : wuri.ratnahidayani@yahoo.co.id
}

\begin{abstract}
A. ABSTRAK
Latar Belakang : Case fatality rate pneumonia di Provinsi Jawa Barat yaitu pada balita $<1$ tahun sebesar 0,11\%, umur 1-4 tahun 0,00\% dan umur 0-4 tahun sebesar 0,04\%. Kabupaten Tasikmalaya menempati peringkat ke 12 se Jawa Barat penemuan kasus pneumonia dan ditangani pada balita yaitu sebanyak 5.351 kasus (34,4\%). Rendahnya cakupan kesehatan balita, perilaku tidak sehat, sosial ekonomi menjadi penyebab morbiditas pneumonia. Beberapa program penanggulangan penyakit ISPA tersebut belum menurunkan kejadian ISPA khususnya pneumonia pada balita.
\end{abstract}

Tujuan : Penelitian ini bertujuan mengetahui faktor-faktor risiko yang berhubungan dengan kejadian pneumonia balita yaitu mengetahui hubungan antara status imunisasi, status pemberian vitamin A, status gizi balita, ASI Ekslusif, BBLR, kebiasaan merokok, kebiasaan membuka jendela, tingkat penghasilan keluarga, program P2 ISPA promosi kesehatan penanggulangan pneumonia, kunjungan rumah pneumonia atau care seeking, pelayanan MTBS dengan kejadian pneumonia balita di Wilayah kerja Puskesmas Sariwangi.

Metode : Jenis penelitian yang digunakan adalah penelitian observasional analitik dengan rancangan kasus kontrol. Pengambilan sampel yang dilakukan di wilayah kerja Puskesmas Sariwangi secara totality sampling, sampel yang diambil 6 bulan terakhir yaitu AgustusJanuari 2018 terdiri dari 21 kasus dan 42 kontrol. Pengumpulan data menggunakan kuesioner. Analisis data yang digunakan adalah analisis univariat, analisis bivariat dan analisis multivariat menggunakan Regresi Logistik.

Hasil : Hasil analisis bivariat (menggunakan tabel $2 \times 2$ ) menunjukkan bahwa secara statistik menunjukkan ada hubungan yang signifikan antara status imunisasi $(\mathrm{OR}=10,0 ; p=0,000)$, status pemberian vitamin A $(\mathrm{OR}=5,55 ; p=0,005)$ ASI Ekslusif $(\mathrm{OR}=4,55 ; p=0,009)$, BBLR $(\mathrm{OR}=6,50 ; p=0,020)$, kebiasaan membuka jendela $(\mathrm{OR}=3,19 ; p=0,044)$, kunjungan rumah pneumonia atau care seeking $(\mathrm{OR}=0,01 ; p=0,000)$, dengan kejadian pneumonia balita di Wilayah kerja Puskesmas Sariwangi. Tidak ada hubungan antara status gizi balita $(\mathrm{OR}=3,08 ; p=0,059)$, kebiasaan merokok $(\mathrm{OR}=1,00 ; p=1,000)$, tingkat penghasilan keluarga $(\mathrm{OR}=1,00 ; p=1,000)$, program $\mathrm{P} 2$ ISPA promosi kesehatan penanggulangan pneumonia $(\mathrm{OR}=1,96 ; p=0,210)$, pelayanan MTBS $(\mathrm{OR}=0,74 ; p=0,582)$ dengan kejadian pneumonia balita di Wilayah kerja Puskesmas Sariwangi Hasil analisis regresi logistik yang memasukkan semua faktor secara bersama-sama diketahui hasil model akhir yaitu kunjungan rumah pneumonia atau care seeking merupakan faktor dominan yang merupakan faktor protektif pneumonia balita.

Kesimpulan : Berdasarkan hasil penelitian ini dapat disimpulkan bahwa kunjungan rumah pneumonia atau care seeking mempunyai hubungan yang bermakna dengan kejadian pneumonia balita di wilayah kerja Sariwangi.

Kata kunci : faktor risiko pneumonia, care seeking, pneumonia 


\section{B. PENDAHULUAN}

Pada tahun 2015 World Health Organization (WHO) melaporkan ada enam juta balita meninggal dunia dan 16 $\%$ dari jumlah tersebut disebabkan oleh pneumonia sebagai pembunuh nomor satu di dunia (Kementerian Kesehatan Republik Indonesia, 2016).Indonesia selalu menempati urutan pertama penyebab kematian ISPA pada kelompok bayi dan balita. Selain itu ISPA juga sering berada pada daftar 10 penyakit terbanyak di rumah sakit. Survei mortalitas menunjukkan bahwa ISPA merupakan penyebab kematian bayi terbesar di Indonesia dengan persentase 22, 30\% dari seluruh kematian balita (Depkes RI, 2010). Provinsi Jawa Barat merupakan provinsi dengan jumlah penemuan kasus pneumonia dan ditangani tertinggi dibandingkan provinsi lainnya di Indonesia yaitu $180.357 \quad(109,74 \%)$. Faktor risiko yang berhubungan dengan kejadian pneumonia pada balita terdiri dari faktor risiko intrinsik yaitu status gizi, status imunisasi, berat badan lahir rendah, pemberian vitamin A, pemberian Air Susu Ibu (ASI) eksklusif dan faktor risiko ekstrinsik yaitu ventilasi, kelembaban, letak dapur, jenis bahan bakar, kebiasaan merokok, tingkat penghasilan (WHO, 2007). Berdasarkan profil kesehatan Jawa Barat tahun 2012 jumlah penemuan kasus pneumonia dan yang ditangani pada balita di Jawa Barat yaitu sebanyak 189.688 kasus. Kabupaten Tasikmalaya menempati peringkat ke 12 se Jawa Barat penemuan kasus pneumonia dan ditangani pada balita yaitu sebanyak 5.351 kasus (34,4\%). Berdasarkan data pada profil Puskesmas di UPT Puskesmas Sariwangi tahun 2016 penemuan kasus pneumonia sebanyak 265 orang dengan cakupan pencapaian sebesar
$27,55 \%$ sedangkan target pencapaian adalah $86 \%$ sehingga kesenjangannya mencapai $58,45 \%$. Pada tahun 2017 terjadi penurunan kasus pneumonia sebanyak 61 orang. Berdasarkan uraian latar belakang di atas peneliti tertarik untuk meneliti faktorfaktor risiko yang berhubungan dengan kejadian pneumonia pada balita di wilayah kerja Puskesmas Sariwangi Kabupaten Tasikmalaya tahun 2018.

\section{METODE PENELITIAN}

Jenis penelitian yang adalah penelitian observasional analitik dengan rancangan kasus kontrol bertujuan untuk mencari hubungan faktor-faktor risiko yang berhubungan dengan pneumonia dengan penelusuran secara retrospektif. Responden adalah ibu dari penderita pneumonia bukan penderita pneumonia berusia 1-5 tahun dan memiliki KMS. Pengambilan sampel yang dilakukan di wilayah kerja Puskesmas Sariwangi secara totality sampling untuk kasus dan consecutive sampling untuk kontrol, sampel yang diambil untuk kasus adalah 6 bulan terakhir yaitu Agustus-Januari 2018 terdiri dari 21 kasus dan 42 kontrol. Pengumpulan data menggunakan kuesioner. Analisis data yang digunakan adalah analisis univariat, analisis bivariat dan analisis multivariat menggunakan Regresi Logistik. Untuk mengetahui kemaknaan hubungan tersebut secara statistik keputusan diambil dengan melihat $P$. value $(<0,05)$ dan atau Confidence Interval tidak mencakup angka 1 . Selain itu mencari perhitungan OR dengan kriteria $\mathrm{OR}=1$ bersifat netral, $\mathrm{OR}<1$ merupakan faktor protektif, $\mathrm{OR}>1$ merupakan faktor risiko. 
1. Karakteristik Subyek Penelitian

Pada penelitian ini karakteristik responden berdasarkan kelompok umur 30-34 tahun (25,4\%). Menurut Sukarto (2016) menyatakan bahwa pada penelitian hubungan peran orang tua dalam pencegahan ISPA dengan kekambuhan ISPA pada balita di Puskesmas Bilalang Kota Kotamobagu karakteristik umur responden lebih dari 30 tahun sebesar 47,5\%. Responden yang bertempat tinggal di Desa Sariwangi dan Desa Jayaputra memiliki proporsi tertinggi sebesar 25,4\%. Pendidikan responden yang memiliki proporsi tertinggi adalah SMP sebesar $52,4 \%$, responden yang berprofesi IRT memiliki proporsi tertinggi sebesar $77,8 \%$. Hal ini disebabkan karena ibu yang berprofesi IRT lebih fokus dalam perawatan balita serta upaya pencegahan penyakit. Responden yang memiliki balita berumur $0-11$ bulan merupakan proporsi tertinggi sebesar $31,7 \%$. Hal ini disebabkan faktor imunitas balita, semakin muda usia balita semakin rentan

\section{HASIL PENELITIAN}

terhadap penyakit. Responden dengan balita berjenis kelamin laki-laki memiliki proporsi paling banyak sebesar $52,4 \%$. Hal ini disebabkan tingkat imunitas balita berjenis kelamin laki-laki dengan perempuan berbeda, selain itu jika ditinjau dari struktur anatomi fisiologis bahwa anatomi saluran pernafasan balita berjenis kelamin lakilaki berbeda ukuran diameternya dengan perempuan. Menurut Hartati (2012) pada penelitian faktor risiko pneumonia menyatakan bahwa responden dengan balita sebagian besar adalah berpendidikan menengah sebesar 56,5 $\%$, karakteristik balita yaitu $\leq 12$ bulan sebesar $37,7 \%$ sedangkan $>12$ bulan sebesar 62,3\%. Penelitian Lestari (2013) menyatakan bahwa responden dengan balita berumur 1 sampai 35 bulan sebesar $60,6 \%$ dan sebagian besar balita berjenis kelamin laki-laki sebesar $51,5 \%$. Sedangkan menurut Kaunang (2016) menyatakan bahwa karakteristik balita mayoritas berjenis kelamin lakilaki sebesar 55,7 \%. 
2. Analisis Bivariat

Tabel 4.20 Hasil Analisis Bivariat Hubungan Variabel Bebas dengan Kejadian Pneumonia pada Balita

\begin{tabular}{|c|c|c|c|c|c|c|c|c|}
\hline \multirow[t]{2}{*}{ No } & \multirow[t]{2}{*}{ Variabel } & \multicolumn{4}{|c|}{\begin{tabular}{c}
\multicolumn{2}{c}{ Kejadian } \\
Pneumonia TDK
\end{tabular}} & \multirow[t]{2}{*}{ OR } & \multirow[t]{2}{*}{$95 \% \mathrm{C1}$} & \multirow[t]{2}{*}{ P-value } \\
\hline & & $\begin{array}{l}\mathbf{n} \\
\%\end{array}$ & $\%$ & & $\mathbf{n}$ & & & \\
\hline \multirow[t]{5}{*}{1} & Status Imunisasi & & & & & & & \\
\hline & Tidak & 14 & 66,6 & 7 & & 10,0 & $2,56-41,55$ & $0,000^{*}$ \\
\hline & $\mathrm{Ya}$ & 33,3 & & & & & & \\
\hline & & 7 & 16,6 & & 35 & & & \\
\hline & & 83,3 & & & & & & \\
\hline \multirow[t]{4}{*}{2} & Status Pemberian Vit A & & & & & & & \\
\hline & Tidak & 9 & 64,3 & 5 & 35,7 & 5,55 & $1,34-24,4$ & $0,005^{*}$ \\
\hline & $\mathrm{Ya}$ & 12 & 24,5 & & 37 & & & \\
\hline & & 75,5 & & & & & & \\
\hline \multirow[t]{3}{*}{3} & Status Gizi Balita & & & & & & & \\
\hline & Tidak & 8 & 53,3 & 7 & 46,6 & 3,08 & $0,80-12,08$ & 0,059 \\
\hline & $\mathrm{Ya}$ & $\begin{array}{l}13 \\
72,9\end{array}$ & 27,0 & & 35 & & & \\
\hline \multirow[t]{3}{*}{4} & ASI Ekslusif & & & & & & & \\
\hline & Tidak & 10 & 58,8 & 741,1 & & 4,55 & $1,21-17,64$ & $0,009^{*}$ \\
\hline & $\mathrm{Ya}$ & $\begin{array}{l}11 \\
76,0\end{array}$ & 23,9 & & 35 & & & \\
\hline \multirow[t]{3}{*}{5} & BBLR & & & & & & & \\
\hline & $\mathrm{Ya}$ & 7 & 70,0 & 330,0 & & 6,50 & $1,25-37,65$ & $0,020^{*}$ \\
\hline & Tidak & 14 & 26,4 & 3973,6 & & & & \\
\hline \multirow[t]{4}{*}{6} & Kebiasaan Merokok & & & & & & & \\
\hline & Tidak & 16 & 33,3 & 32 & 2 & 1,00 & $0,25-4,08$ & 1,000 \\
\hline & $\mathrm{Ya}$ & 66,6 & & & & & & \\
\hline & & $\begin{array}{c}5 \\
66,6\end{array}$ & 33 , &, 3 & 10 & & & \\
\hline \multirow[t]{3}{*}{7} & $\begin{array}{l}\text { Kebiasaan Membuka } \\
\text { Jendela }\end{array}$ & & & & & & & \\
\hline & Tidak & 9 & 52,9 & 8 & 47,1 & 3,19 & $0,87-11,95$ & $0,044^{*}$ \\
\hline & $\mathrm{Ya}$ & 12 & 26,1 & 134 & 73,9 & & & \\
\hline
\end{tabular}




\begin{tabular}{llrrrrrrr|}
8 & $\begin{array}{l}\text { Penghasilan Keluarga } \\
<\text { UMR }\end{array}$ & 12 & 33,3 & 24 & 66,6 & 1,00 & $0,31-3,29$ & 1,000 \\
& $>$ UMR \\
& 9 & 33,3 & 18 & 66,6 & & & \\
9 & & & & & & & \\
& P2 ISPA Promosi & & & & & & & \\
& Kesehatan Pneumonia & 12 & 41,3 & 17 & 58,6 & 1,96 & $0,60-6,50$ & 0,210 \\
& Tidak & 9 & 26,4 & 25 & 73,5 & & & \\
Ya & & & & & & &
\end{tabular}

\begin{tabular}{|c|c|c|c|c|c|c|}
\hline \multirow[t]{2}{*}{ No } & \multirow[t]{3}{*}{ Variabel } & \multicolumn{2}{|c|}{ Kejadian } & \multirow[t]{3}{*}{ OR } & \multirow[t]{3}{*}{$95 \%$ C1 } & \multirow[t]{3}{*}{ P-value } \\
\hline & & Pneumonia & TDK & & & \\
\hline & & $\%$ & $\%$ & & & \\
\hline
\end{tabular}

10. P2 ISPA Kunjungan

Pneumonia

$\begin{array}{llllllll}\text { Tidak } & 2 & 4,87 & 39 & 95,1 & 0,01 & 0,00-0,06 & 0,000 *\end{array}$

$\begin{array}{lllll}\text { Ya } & 19 & 86,3 & 3 & 13,6\end{array}$

11 P2 ISPA Pelayanan

MTBS

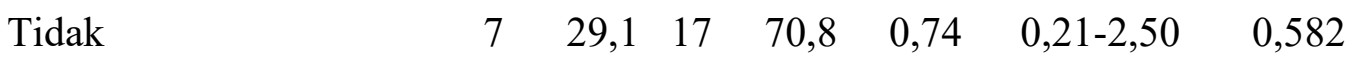

$\begin{array}{lllll}\text { Ya } & 14 & 35,9 & 25 & 64,1\end{array}$

Berdasarkan hasil analisis statistik bivariat faktor risiko yang mempunyai hubungan yang signifikan dan dapat dianalisis multivariat menggunakan multiple logistic regression adalah : Status imunisasi balita, Status pemberian vitamin A balita, Status gizi balita, ASI Ekslusif, BBLR, Kebiasaan membuka jendela, P2 ISPA Promosi Kesehatan, P2 ISPA Kunjungan pneumonia. Hasil analisis multivariat menggunakan metode enter. Hasil analisis multivariat dapat dilihat pada tabel 4. sebagai berikut : 
Tabel 4. Analisis Multivariat Beberapa Variabel

\begin{tabular}{|l|c|c|c|c|c|}
\hline Variabel & \multicolumn{1}{|c|}{$\beta$} & \multicolumn{1}{c|}{$S . E}$. & $\operatorname{Exp}(\beta)$ & $95 \% \mathrm{Cl}$ & \multicolumn{1}{c|}{$p$} \\
\hline Status imunisasi &,- 554 & 1,360 & 0,574 & $0,040-8,262$ & 0,684 \\
\hline $\begin{array}{l}\text { Status pemberian } \\
\text { vitamin A }\end{array}$ &,- 048 & 1,245 & 0,954 & $0,083-10,932$ & 0,969 \\
\hline Status gizi balita &,- 346 & 1,712 & 0,708 & $0,025-20,273$ & 0,840 \\
\hline ASI Ekslusif &, 567 & 1,820 & 1,763 & $0,050-62,407$ & 0,755 \\
\hline BBLR & 1,366 & 1,635 & 3,922 & $0,159-95,645$ & 0,403 \\
\hline $\begin{array}{l}\text { Kebiasaan membuka } \\
\text { jendela }\end{array}$ &,- 890 & 1,223 & 0,410 & $0,037-4,510$ & 0,467 \\
\hline $\begin{array}{l}\text { P2 ISPA Promosi } \\
\text { Kesehatan }\end{array}$ & $-1,380$ & 1,344 & 0,252 & $0,018-3,506$ & 0,305 \\
\hline $\begin{array}{l}\text { P2 ISPA Kunjungan } \\
\text { Pneumonia }\end{array}$ & 4,894 & 1,331 & $\begin{array}{r}133,5 \\
39\end{array}$ & $9,823-1815,313$ & $0,000 *$ \\
\hline
\end{tabular}

-2 Log likelihood $=28,80$ Overall Percentage $=92,1$

Berdasarkan Tabel 4. Dapat diketahui bahwa hasil analisis multivariat menunjukkan hanya satu variabel yang bermakna secara statistik adalah variabel kunjungan rumah pneumonia $\mathrm{p}=0,000 ; \operatorname{Exp}(\beta)=133,159$ dan CI 95\%: 9, 823-1815,313. Pada analisis ini diperoleh hubungan antara variabel bebas dan variabel terikat dengan nilai -2 Log likelihood sebesar 28,805 cox \& Snell $R$ Square sebesar 0,558 dan overall percentage 92,1 , dengan melihat nilai overall percentage maka terdapat 7,9\% kasus disebabkan oleh faktor risiko lain. Kemampuan memprediksi kejadian DBD sebesar 92,1\%.

\section{E. PEMBAHASAN}

1. Hubungan Status Imunisasi Balita dengan Kejadian Pneumonia pada Balita

Berdasarkan hasil penelitian bahwa ada 42 subyek $(66,7 \%)$ yang mengimunisasi balita dengan lengkap dan ada 21 subyek (33,3 $\%$ ) yang tidak mengimunisasi balita secara tidak lengkap. Hasil analisis bivariat menunjukkan OR sebesar 10,0 dengan CI $95 \%: 2,56-41,55$ dan nilai $\mathrm{p}=0,000$, yang berarti secara statistik ada hubungan yang bermakna, oleh sebab itu variabel status imunisasi dimasukkan ke dalam analisis multivariat, dari hasil analisis multivariat menunjukkan nilai $\operatorname{Exp}(\beta)=0,573$ dengan CI 95\% : 0,040-8,262 dan nilai $p=0,684$, dengan demikian status imunisasi tidak

mempunyai hubungan yang bermakna namun merupakan faktor risiko kejadian pneumonia karena $\mathrm{OR}>1$. Adanya beberapa informasi pentingnya imunisasi bagi balita melalui televisi, surat kabar, buku, internet dan promosi kesehatan dari petugas dan kader kesehatan. Meningkatnya pengetahuan dan kesadaran masyarakat tentang imunisasi dapat memberikan dampak positif masyarakat untuk mengimunisasi balita sehingga sebagai upaya specifik protection terhadap kejadian pneumonia balita. Selain itu berdasarkan laporan data di Puskesmas Sariwangi ada penderita pneumonia walaupun sudah diimunisasi memiliki riwayat komplikasi penyakit lain sehingga harus dirujuk ke Rumah Sakit. Menurut 
Najmah (2015) menyatakan pencegahan ISPA termasuk pneumonia dengan melakukan imunisasi lengkap pada anak sehingga tidak mudah terserang penyakit yang disebabkan oleh virus dan penyakit. Selain itu imunisasi influenza diberikan jika diperlukan. Kementrian Kesehatan melaksanakan program Pengembangan Imunisasi (PPI) pada anak dalam upaya menurunkan kejadian penyakit yang dapat dicegah dengan imunisasi (PD3I) meliputi tuberkulosis, difteri, pertusis, campak, polio, tetanus, serta hepatitis B.

2. Hubungan antara status pemberian vitamin A dengan kejadian pneumonia pada balita

Berdasarkan hasil penelitian bahwa ada 49 subyek yang memberikan vitamin A lengkap pada balita (77,8 \%) dan 14 subyek yang tidak memberikan vitamin $\mathrm{A}$ dengan lengkap pada balita (22,2\%). Hasil analisis bivariat menunjukkan OR sebesar 5,55 dengan CI $95 \%$ : 1,34-24,4 dan nilai $\mathrm{p}=0,005$, yang berarti secara statistik ada hubungan yang bermakna, oleh sebab itu variabel pemberian vitamin A dimasukkan ke dalam analisis multivariat, dari hasil analisis multivariat menunjukkan nilai Exp $(\beta)=0,954$, dengan CI 95\%:0,083-10,935 dan nilai $p=0,969$, dengan demikian pemberian vitamin A pada balita tidak mempunyai hubungan yang bermakna namun merupakan faktor risiko kejadian pneumonia karena $\mathrm{OR}>1$. pemberian vitamin A bukan satu-satunya faktor yang berhubungan dengan kejadian pneumonia, karena suatu kejadian penyakit disebabkan oleh multiple causation, serta jumlah sampel yang kurang mencukupi sehingga mempengaruhi dalam perhitungan statistik. Menurut Ramezani (2015) pada penelitian Factors Affecting the Rate of Pediatric Pneumonia in Developing Countries: a
Review and Literature Study menyatakan bahwa defisiensi vitamin A tubuh mudah terserang penyakit infeksi seperti pneumonia karena keratinisasi mukosa saluran pernafasan dan penurunan fungsi cilia serta mukus pada sel epitel saluran pernafasan.

3. Hubungan antara status gizi dengan pneumonia pada balita

Berdasarkan hasil penelitian bahwa ada 48 subyek (76,2\%) yang status gizi balita baik dan 15 subyek $(23,8 \%)$ yang status gizi balita kurang. Hasil analisis bivariat menunjukkan OR sebesar 3,08 dengan CI 95\%: 0,80-12,08, dan nilai $\mathrm{p}=0,059$ yang berarti secara statistik tidak ada hubungan yang bermakna namun merupakan faktor risiko kejadian pneumonia $\mathrm{OR}>1$. Pada analisis ini nilai $\mathrm{p}<0,25$ sehingga dimasukkan ke dalam analisis multivariat, dari hasil analisis multivariat menunjukkan nilai $\operatorname{Exp}(\beta)=0,708$ dengan $C I \quad 95 \%$ : $0,025-20,273$ dan nilai $p=0,840$, dengan demikian status gizi balita tidak mempunyai hubungan yang bermakna namun merupakan faktor risiko kejadian pneumonia karena $\mathrm{OR}>1$. Hal ini disebabkan proporsi responden dengan balita status gizi baik lebih banyak dibandingkan dengan status gizi kurang yang menunjukkan adanya kesadaran masyarakat akan pentingnya kecukupan gizi bagi balita sebagai upaya preventif penyakit infeksi seperti pneumonia. Menurut Srivastava (2015) menyatakan bahwa malnutrisi merupakan faktor predisposing pneumonia balita di Rumah Sakit Jamdshedpur India Periode Maret 2013-Februari 2014. Pada analisis multivariat malnutrisi merupakan faktor yang paling dominan pneumonia balita. Di New Delhi balita berumur 2 minggu sampai dengan 5 tahun dengan malnutrisi 
merupakan kelompok berisiko Acute Lower Respiratory Infections (ALRI) yang diprediksi penyebab kematian.

\section{Hubungan antara ASI Ekslusif dengan Pneumonia Balita}

Berdasarkan hasil penelitian bahwa ada 46 subyek (73,0\%) yang memberikan ASI Ekslusif kepada balita dan ada 17 subyek (27,0\%) yang tidak memberikan ASI Ekslusif. Hasil analisis bivariat menunjukkan OR sebesar 4,55 dengan CI $95 \%=1,21-17,64$ dan nilai $p=0,009$ yang berarti secara statistik ada hubungan yang bermakna, oleh sebab itu variabel pemberian ASI Ekslusif dimasukkan ke dalam analisis multivariat, dari hasil analisis multivariat menunjukkan nilai Exp $(\beta)=1,763$ dengan CI 95\% 0,050-62,407 dan nilai $\mathrm{p}=0,755$, dengan demikian ASI Ekslusif pada balita tidak mempunyai hubungan yang bermakna namun merupakan faktor risiko kejadian pneumonia karena $\mathrm{OR}>1$. Mayoritas responden memberikan ASI Ekslusif. Responden yang tidak memberikan ASI Ekslusif menyatakan hanya memberikan ASI sampai usia 3-5 bulan. Berdasarkan wawancara yang dilakukan alasan memberikan ASI Eksusif yaitu karena ASI yang pertama kali keluar mengandung kolostrum yang memberikan perlindungan balita terhadap infeksi. Pemberian ASI Ekslusif selama 6 bulan merupakan upaya specific protection bagi balita terhadap penyakit infeksi salah satunya pneumonia karena dalam ASI mengandung Imunogloblin A yang berfungsi sebagai protektif terhadap kuman patogen, mengikat bakteri sehingga menetralisir racun, preventif kontak antara racun dengan virus sehingga balita yang mendapat ASI imunitasnya lebih baik daripada yang tidak. Penelitian ini sejalan dengan Wicaksono (2015) menyatakan tidak ada hubungan antara pemberian ASI Ekslusif dengan kejadian pneumonia di Wilayah Kerja Puskesmas Gane Luar Halmahera Selatan.

\section{Hubungan antara BBLR dengan pneumonia pada balita}

Berdasarkan hasil penelitian proporsi responden dengan balita tidak BBLR lebih banyak daripada yang BBLR. Ada 53 responden dengan balita tidak BBLR $(84,1 \%)$ dan ada 10 responden dengan balita BBLR (15,9\%). Hasil analisis bivariat menunjukkan OR sebesar 6,50 dengan CI $95 \%$ : 1,25-37,65 dan nilai $p=0,020$ yang berarti secara statistik ada hubungan yang bermakna, oleh sebab itu variabel BBLR dimasukkan ke dalam analisis multivariat, dari hasil analisis multivariat menunjukkan nilai Exp $(\beta)=3,922$ dengan CI 95\%: 0,159-95,645 dan nilai $p=0,403$ dengan demikian BBLR tidak mempunyai hubungan yang bermakna namun merupakan faktor risiko kejadian pneumonia karena $\mathrm{OR}>1$. Hal ini disebabkan jumlah sampel yang kurang memenuhi dalam penelitian ini. Balita yang BBLR imunitasnya belum sempurna sehingga rentan terhadap penyakit infeksi seperti pneumonia. Fonseca Lima (2016) menyatakan bahwa bayi prematur dapat dicegah selama proses kehamilan sehingga bayi lahir dengan berat normal karena bayi yang prematur merupakan salah satu risiko pneumonia dan kematian.

\section{Hubungan antara Kebiasaan Merokok dengan pneumonia balita}

Berdasarkan analisis univariat ada 48 subyek (76,2 \%) yang memiliki kebiasaan merokok, sedangkan yang tidak merokok ada 15 subyek (23,8\%). Hasil analisis bivariat menunjukkan OR sebesar 1,00 
dengan CI 95\% : 0,25-4,08 dan nilai $\mathrm{p}=$ 1,000 secara statistik tidak ada hubungan yang bermakna sehingga variabel kebiasaan merokok tidak dimasukkan dalam analisis multivariat, karena $\mathrm{OR}=1$ artinya variabel kebiasaan merokok dalam rumah bersifat netral terhadap kejadian pneumonia balita.. Hal ini disebabkan proporsi responden dengan pneumonia dan tidak mayoritas salah satu anggota keluarganya merokok di dalam rumah. Balita yang terpapar dengan asap rokok akan meningkatkan risiko kerusakan organ pernafasan sehingga berisiko pada kejadian pneumonia dan menjadi penyebab mortalitas pada balita. Srivastava (2015) menyatakan bahwa perilaku merokok tidak bermakna secara statistik dengan kejadian pneumonia balita di Rumah Sakit Jamdshedpur India. Hal ini karena ayah dari balita yang merokok di dalam rumah bisa dicegah dengan menyarankan merokok di luar rumah.

7. Hubungan antara Kebiasaan membuka jendela dengan pneumonia

Berdasarkan analisis univariat ada 46 subyek $(73,0 \%)$ yang memiliki kebiasaan membuka jendela pada pagi hari dan ada 17 subyek $(27,0 \%)$ yang tidak memiliki kebiasaan membuka jendela pada pagi hari. Hasil analisis bivariat menunjukkan OR sebesar 3,19 dengan CI 95\%: 0,8711,95 dan nilai $p=0,044$, yang berarti secara statistik ada hubungan yang bermakna oleh sebab itu variabel kebiasaan membuka jendela dimasukkan ke dalam analisis multivariat menunjukkan nilai Exp ( $\beta)=0,410$ dengan CI 95\%: 0,037-4,510 dan nilai $p=0,467$ dengan demikian variabel kebiasaan membuka jendela tidak ada hubungan dengan kejadian pneumonia namun merupakan faktor risiko kejadian pneumonia $(\mathrm{OR}>1)$. Proporsi responden yang membuka jendela lebih banyak daripada yang tidak membuka jendela di pagi hari menunjukkan sebagian besar responden memahami pentingnya membuka jendela pada pagi dan siang hari untuk pergantian sirkulasi udara, mencegah agar ruangan tidak pengap dan lembab sehingga mencegah tumbuhnya kuman penyebab penyakit infeksi. Menurut Sartika (2011) menyatakan ada hubungan antara perilaku membuka jendela dengan kejadian pneumonia di Kabupaten Kubu Raya.

\section{Hubungan antara Penghasilan Keluarga dengan Pneumonia Balita}

Berdasarkan analisis univariat ada 36 subyek $(57,1 \%)$ dengan penghasilan $<$ UMR dan ada 27 subyek dengan penghasilan $>$ UMR $(42,9 \%)$. Hasil analisis bivariat menunjukkan OR sebesar 1,00 dengan CI 95\%: 0,31-3,29 dan nilai $\mathrm{p}=1,000$ secara statistik tidak ada hubungan yang bermakna sehingga variabel penghasilan keluarga tidak dimasukkan dalam analisis multivariat, karena $\quad \mathrm{OR}=1 \quad$ sehingga variabel penghasilan keluarga bersifat netral terhadap kejadian pneumonia balita. Hal ini disebabkan sampel size yang tidak mencukupi pada penelitian ini. Fonseca Lima (2016) menyatakan ada hubungan antara penghasilan keluarga dengan kejadian pneumonia pada balita di Rumah Sakit di Brazil. Tingkat sosial ekonomi keluarga meningkatkan akses terhadap pelayanan kesehatan khususnya balita dalam pencegahan penyakit infeksi seperti pneumonia salah satunya dengan mendapatkan vaksinasi pada balita di Brazil. 
9. Hubungan antara P2 ISPA Promosi Kesehatan Pneumonia dengan Kejadian Pneumonia pada Balita

Berdasarkan analisis univariat dapat diketahui bahwa ada 34 subyek (54,0\%) yang pernah mengikuti promosi kesehatan pneumonia dan ada 29 subyek (46,0\%) yang tidak pernah mengikuti promosi kesehatan pneumonia. Hasil analisis bivariat menunjukkan OR sebesar 1,96 dengan CI 95\%: 0,60-6,50 dan nilai $\mathrm{p}=0,210$, karena nilai $\mathrm{p}<0,25$ maka varibel P2 ISPA Promosi kesehatan pneumonia dimasukkan ke dalam analisis multivariat yang menunjukkan nilai $\operatorname{Exp}(\beta)=0,252$ dengan CI 95\% :0,018-3,506 dan nilai $p=0,305$, dengan demikian program $\mathrm{P} 2$ ISPA promosi kesehatan tidak mempunyai hubungan yang bermakna namun merupakan faktor risiko kejadian pneumonia karena $\mathrm{OR}>1$. Hal ini disebabkan proporsi responden yang mendapatkan promosi kesehatan lebih banyak daripada yang tidak sehingga adanya peningkatan pengetahuan tentang faktor risiko dan upaya pencegahan pneumoni. Dalam epidemiologi pneumonia health promotion merupakan upaya pencegahan primer penyakit pneumonia yang merupakan salah satu five level of prevention penyakit pneumonia. Mayasari (2016) menyatakan media booklet efektif dalam meningkatkan ibu tentang pneumonia di Kelurahan Bandarharjo Kota Semarang Tahun 2014.

10.Hubungan antara Program P2 ISPA Kunjungan Rumah Pneumonia dengan Kejadian Pneumonia pada Balita

Berdasarkan analisis univariat dapat diketahui bahwa ada 22 subyek (34,9\%) yang dikunjungi oleh kader maupun petugas kesehatan dan ada 41 subyek
$(65,1)$ yang tidak dikunjungi oleh kader maupun petugas kesehatan. Analisis bivariat menunjukkan OR sebesar 0,01 dengan CI 95\%: 0,00-0,006 dengan nilai $p=0,000$, secara statistik ada hubungan antara program P2 ISPA kunjungan rumah pneumonia dengan kejadian pneumonia namun karena $\mathrm{OR}<1$ merupakan faktor protektif terhadap kejadian pneumonia, setelah dimasukkan dalam analisis multivariat menunjukkan $\operatorname{Exp}(\beta)=133,539$ dengan CI 95\%: 9,823-1815,313, dan nilai $p=0,000$, dapat disimpulkan bahwa variabel ini merupakan faktor yang paling dominan dalam kejadian pneumonia. Hal ini menunjukkan bahwa kader kesehatan maupun petugas kesehatan di Puskesmas Sariwangi sudah melaksanakan tugas pokok fungsinya dalam melakukan kunjungan rumah pneumonia serta terus melakukan pencarian aktif penderita pneumonia pada balita dalam upaya pencegahan dan penanggulangan pneumonia. Penelitian Geldsetzer (2014) menyatakan bahwa perilaku care seeking salah satunya pneumonia oleh petugas kesehatan merupakan rencana aksi global dalam upaya menurunkan angka kesakitan pneumonia balita di negara-negara berkembang.

11.Hubungan antara Program P2 ISPA
Pelayanan MTBS dengan Kejadian Pneumonia balita

Berdasarkan analisis univariat ada 36 subyek $(57,1 \%)$ yang mendapatkan pelayanan MTBS dan 27 subyek yang tidak mendapatkan pelayanan MTBS (42,9\%). Hasil analisis bivariat menunjukkan bahwa OR sebesar 0,74 dengan CI 95\%: 0,21-2,50,dan nilai $p=0,582$, secara statistik tidak mempunyai hubungan yang bermakna $(\mathrm{p}>0,05)$ namun karena nilai $\mathrm{OR}<1$ maka variabel program 
P2 ISPA pelayanan MTBS merupakan faktor protektif terhadap kejadian pneumonia. Hal ini disebabkan sampel size yang tidak mencukupi dalam penelitian ini. Selain itu tersedianya sarana MTBS yang baik di Puskesmas Sariwangi seperti ruang MTBS, formulir MTBS, kartu nasihat ibu, peralatan MTBS seperti thermometer, stetoskop, timer ISPA atau pneumonia atau arloji. Sedangkan obat-obatan MTBS berada di ruangan obat karena keterbatasan ruangan. Petugas MTBS sudah baik dalam melaksanakan tugas pokok dan fungsinya berdasarkan wawancara dengan responden menyatakan bahwa petugas kesehatan selalu menanyakan keluhan tentang gejala yang dialami balita, memberikan solusi setiap permasalahan balita sakit yang dihadapi responden, petugas selalu memotivasi, pesan yang disampaikan jelas dan mencatat hasil pemeriksaan dengan prosentase yang sama masing-masing sebesar $57,1 \%$ namun sistem pencatatan MTBS belum maksimal karena belum menggunakan software komputer. Penelitian Hidayati (2011) menyatakan perilaku petugas dalam pelayanan berbasis MTBS tidak mempengaruhi kejadian pneumonia balita di Puskesmas Bergas Kabupaten Semarang. Sedangkan tata laksan pelayanan puskesmas dan sarana pendukung MTBS mempengaruhi kejadian pneumonia balita di Puskesmas Bergas Kabupaten Semarang. Menurut Kemenkes RI (2012) rendahnya angka cakupan penemuan pneumonia balita disebabkan antara lain karena sistem pelaporan belum maksimal, deteksi kasus di puskesmas masih rendah dan kelengkapan pelaporan terutama dari kabupaten/kota ke provinsi masih rendah.

\section{F. SIMPULAN SARAN}

Berdasarkan hasil analisis dan pembahasan dapat disimpulkan sebagai berikut :

1. Program P2 ISPA kunjungan rumah pneumonia/care seeking mempunyai hubungan yang bermakna dengan kejadian pneumonia balita di Wilayah Kerja Puskesmas Sariwangi. Variabel Program P2 ISPA kunjungan rumah pneumonia/care seeking merupakan faktor yang paling dominan dan merupakan faktor protektif kejadian pneumonia balita di Wilayah Kerja Puskesmas Sariwangi.

2. Tidak ada hubungan yang bermakna antara status imunisasi, status pemberian vitamin A, status gizi balita, ASI Ekslusif, BBLR, keberadaan anggota keluarga yang merokok di dalam rumah, kebiasaan membuka jendela, tingkat penghasilan keluarga, program P2 ISPA promosi kesehatan penanggulangan pneumonia, dan program P2 ISPA pelayanan manajemen tepadu balita sakit (MTBS) dengan kejadian pneumonia pada balita di Wilayah Kerja Puskesmas Sariwangi.

Berdasarkan pengamatan langsung di lapangan, melakukan analisis dan pembahasan, maka beberapa saran sebagai berikut:

\section{Kepada Masyarakat}

Diharapkan ada kerjasama yang maksimal antara masyarakat dengan petugas kesehatan serta berperan aktif dalam upaya pencegahan dan penanggulangan pneumonia balita dengan upaya five level of prevention pneumonia terutama upaya health promotion dan specific protection.
2. Kepada Dinas Kesehatan
Kabupaten Tasikmalaya
Mengadakan pelatihan dan peningkatan pemahaman kepada petugas kesehatan 
puskesmas dalam peningkatan program P2 ISPA khususnya promosi kesehatan, kunjungan rumah dan penemuan kasus pneumonia serta pelayanan MTBS.

3. Kepada Puskesmas Sariwangi Diharapkan lebih memperhatikan ketelitian, keakuratan rekam medis pneumonia, pencatatan data dengan software komputer serta kelengkapan pelaporan dalam surveilens P2 ISPA ke Kabupaten Tasikmalaya sehingga mendukung program P2 ISPA dalam upaya pencegahan dan penanggulangan pneumonia balita.

4. Kepdaa Kader dan Petugas Kesehatan

Meningkatkan dalam tugas, pokok dan fungsinya dalam promosi kesehatan pneumonia seperti penyuluhan faktor risiko pneumonia, mengkampanyekan pentingnya specific protection pneumonia bagi balita seperti imunisasi dan vitamin A, kunjungan rumah pneumonia atau care seeking serta pelayanan MTBS.

\section{G. DAFTAR PUSTAKA}

Kemenkes RI. 2012. Pedoman Pengendalian Infeksi Saluran Pernafasan akut . Kementerian Kesehatan Republik Indonesia Direktorat Jenderal Pengendalian Penyakit dan Penyehatan Lingkungan. Jakarta.

Dinas Kesehatan Provinsi Jawa Barat. 2012. Profil Kesehatan Provinsi Jawa Barat Tahun 2012. Dinas Kesehatan Provinsi Jawa Barat. Jawa Barat

Departemen Kesehatan RI, 2008. Perawatan ISPA pada Balita. Depkes RI, Jakarta

Dinas Kesehatan Tasikmalaya, 2016. Profil Dinas Kesehatan Kabupaten
Tasikmalaya, Dinkes Tasikmalaya, Tasikmalaya

Direktorat Jenderal Pengendalian Penyakit dan Penyehatan Lingkungan. 2015. Rencana Aksi Program Pengendalian Penyakit dan Penyehatan Lingkungan Tahun 2015-2019. Dirjen P2PL. Jakarta

Direktorat

Surveilens,Imunisasi,Karantina dan Kesehatan Matra Direktorat Jenderal PP \& PL Kemenkes RI.2014. Program Imunisasi Ibu Hamil, Bayi dan Batita Di Indonesia. Jakarta

Hartati. 2011. Faktor Risiko Terjadinya Pneumonia pada Balita. Universitas Indonesia. Jakarta

Lemeshow, S., and Lwanga, S.K.,1991, Sampel Size Determination In Health Studies. WHO. Geneva.

Lestari, R. 2008. Pengaruh pendidikan kesehatan tentang infeksi saluran pernapasan atas (ISPA) terhadap kemampuan ibu dalam perawatan ISPA pada balita. Di dusun Lemahdadi Kasihan Bantul. Skripsi Strata Satu. Universitas Muhammadiyah Yogyakarta. Yogyakarta

Sukarto, Riska Cahya W., Ismanto, Amatus Yudi; Karundeng, Michael. 2016. Hubungan Peran Orang Tua Dalam Pencegahan ISPA dengan Kekambuhan ISPA pada Balita di Puskesmas Bilalang Kota Kotamobagu. Jurnal Keperawatan Volume 4 Nomor 1, Mei 2016. Diakses 28 Desember 2017.

Najmah, 2016. Epidemiologi Penyakit Menular. Trans Info Media. Jakarta 
Ramezani, Monir; Aemmi, Seyedeh Zahra; Mongadam, Zahra Emami. 2015. Factors Affecting the Rate of Pediatric Pneumonia in Developing Countries: a Review and Literature Study. Int J Pediatr, Vol.3, N.6-2, Serial No.24, Dec 2015.

Srivastava, Preeti; Mishra, Asit Kumar; Roy, Ashish Kumar. 2015. Predisposing Factors of Community Acquired Pneumonia in Under-Five Children. Journal of Lung Diseases \& Treatment. Treat 2015, 1:1 DOI: 10.4172/2472-1018.1000101.

Fonseca Lima, Eduarto Jorge et al. 2016. Risk factors for communityacquiredpneumonia in children under five years ofage in the post-pneumococcal conjugatevaccine era in Brazil: a case control study

Geldsetzer, Pascal et al. 2014. The Recognition of and Care Seeking Behaviour for Childhood Illness in Developing Countries: A Systematic Review. $\quad$ http://nrs.harvard.edu/urn-
3:HUL.InstRepos:12185814 diakses 5 Mei 2018.

Wicaksono, Henry. 2015. Nutritional Status Affects Incidence of Pneumonia in Underfives. Folia Medica Indonesiana Vol.51 No.4 OctoberDecember 2015: 285-291.

Mayasari, Maria Listri; Wahyono, Bambang. 2016. Efektivitas Penyuluhan Kesehatan Dengan Metode Ceramah Disertai Pemanfaatan Media Booklet dalam Upaya Meningkatkan Pengetahuan Ibu tentang Penyakit Pneumonia pada Balita di Kelurahan Bandarharjo Kecamatan Semarang Utara Kota Semarang tahun 2014. UJPH 5 (1) (2016) Unnes Journal of Public Health http://journal.unnes.ac.id/sju/index.php/ujp $\underline{h}$ diakses tanggal 5 Mei 2018. 